\title{
ENCOURAGING STUDENTS TO WRITE A PARAGRAPH BY USING SEMANTIC MAPPING STRATEGY
}

\author{
Teguh Sulistyo and M.G. Sri Ningsih \\ Kanjuruhan University of Malang \\ teguhforever@yahoo.com
}

\begin{abstract}
Of four English language skills, writing is considered the most difficult skill which must be mastered by Indonesian students since it is a very complex process that drives students to explore their thoughts, experiences, schemata, and ideas. Due to the problems faced by the students of Kanjuruhan University in creating ideas related to the topic and construct the ideas into a good unity of a paragraph, this study was conducted to facilitate the students to compose a descriptive paragraph. The findings of the research, taken at Kanjuruhan University of Malang, proved that Semantic Mapping strategy was valuable to increase the students' writing skills.
\end{abstract}

Keywords: Semantic Mapping strategy, descriptive paragraph

English as a foreign language (EFL) is given in Indonesia since elementary school up to university level. The purpose of providing English language teaching and learning in this country is to facilitate students to master English skills namely listening, speaking, reading, and writing.

The four skills are divided into two big pots: receptive skills - listening and reading, and productive skills - speaking and writing. Receptive skills (listening and reading) are the ways in which people extract meaning from the discourse they see and hear (Harmer, 2003:199). Meanwhile, productive skills (speaking and writing) are different in many ways. However, there are a number of language production processes which have to be gone through whichever medium we are working in (Harmer, 2003:246).

Of four English language skills, writing is considered the most difficult skill which must be mastered by Indonesian students since it is a very complex process that drives students to explore their thoughts, experiences, sche- mata, and ideas. The students must be able to write many things in their daily lives. Accordingly, they must be taught how essential writing is as well as the processes of writing. Meanwhile, getting stuck of writing in any language may come from the students' shortage of practice writing or insufficient support from people surroundings especially from teachers.

Meanwhile, I found students of Kanjuruhan University of Malang still got difficulties organizing their ideas into a good descriptive paragraph. A paragraph is a group of related sentences about a single topic (Hogue, 1996:3). The major difficulty faced by the students was creating ideas related to the topic and construct the ideas into a good unity of paragraph. The problem led the students to produce shallow content, and even their ideas were not organized well. It motivated me to help them organize their ideas before writing the first rough draft.

In addition, the teaching of writing has moved away from a concentration on writ- 
ten product to an emphasis on the process of writing. In this approach, students are trained to generate ideas for writing, think of the purpose and audience, and write multiple drafts in order to present written products that communicate their own ideas.

Being inspired by the importance of the process of writing and the necessities to help my students, I applied Semantic Mapping strategy in pre-writing activity.

Semantic Mapping Strategy and Its Application

A teacher should take time to ensure that students understand how the classroom structure and instructional activities work together. It is important to create an atmosphere that allows and encourages students to be brave to develop their ideas, thoughts, and schemata on a topic. In this context, the teacher is a facilitator for the students. Of course, the teacher plays an interactive role and builds scaffolds as needed.

Semantic mapping strategy can be applied well in helping students in writing. Semantic mapping strategy is defined by Burns as a diagram that helps students to see how words are related to one another. Students learn the meanings and uses of new words, see old words in a new perception, and see relationships among words (1996:182). Semantic mapping is a good pre-writing strategy because it introduces important terms or vocabulary items that the students will encounter in their writing related to the topic given that is being discussed. According to Roe, charts and diagrams are designed to help students picture the events, processes, structures, relationships, or sequences described by the texts (1995:172).
To construct a semantic mapping in a class, the teacher writes on the blackboard or a chart a word that represents a concept that is a central to the topic under consideration. The teacher asks the students to mention some words related to this concept. The students notions are written on the blackboard grouped in broad categories.

The diagram reflects the students' ideas concerning with the description of 'Thukul Arwana'. It is almost like drawing a map of students' thoughts using circles, lines, arrows, and words. It is the technique aimed at pulling as many different related thoughts out of the students' mind as possible. Thus, the diagram helps the teaching-learning process more alive as all members in the classroom have the right to show their ideas under the topic selected.

Then the discussion of mapping above can be gained better if the teacher is the motivator or facilitator and the students are the subject learning the topic or material. In other words, the teaching-learning process is the students centered class whereas the students are supported to be actively involved in the teachinglearning process. After the students get the semantic map of 'Thukul Arwana', the teacher leads them to generalize each description. Of course, the students have to think about the topic in the term of a class discussion. All students actively propose their ideas by the help of the teacher. As soon as the terms needed have been completed, the students start to write or make a draft of their writing work. The diagram or chart will lead them to construct their draft in a chronological composition as it is based on the terms or vocabulary items which have been discussed. The diagram also helps students avoid from loosing the terms needed in writing. 


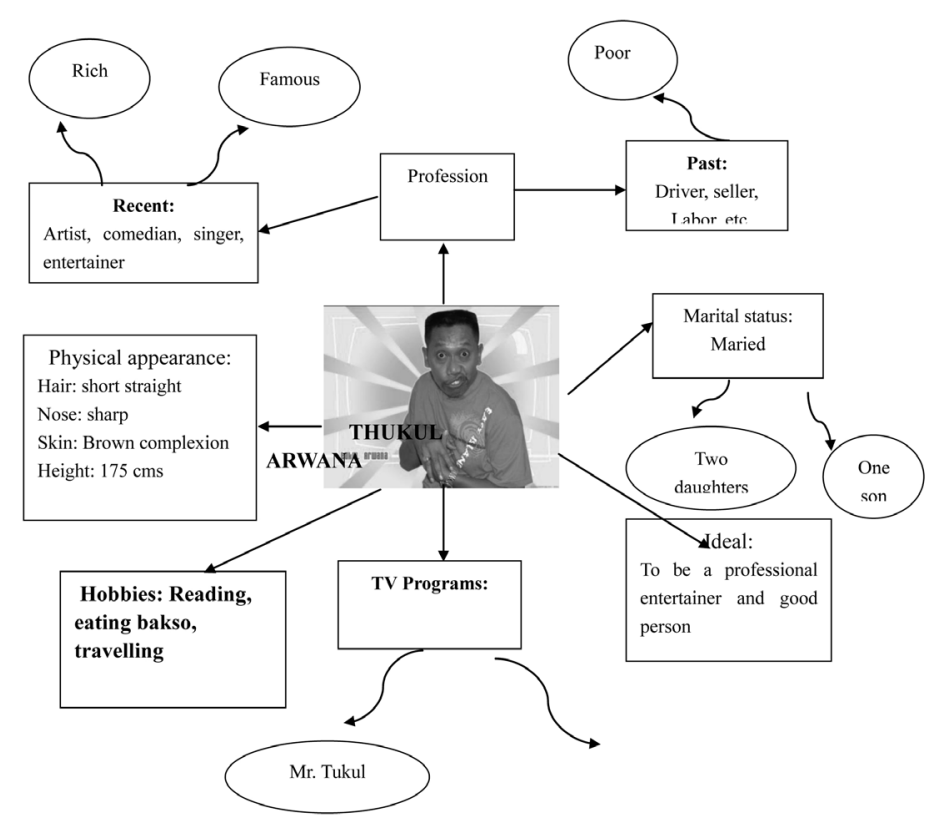

Figure 1. Semantic Mapping about Thukul Arwana

In addition, Semantic Mapping strategy planned by the teacher can serve as writing scaffolds for students who have difficulty accessing their own feelings, ideas, experiences, and knowledge. Teacher-planned pre-writing activities such as the samples above, give students a place to start and make them become aware of places from which to get ideas in the future. Somehow, the teacher should also realize the time allotment to do such kinds of activities in Semantic Mapping strategy. Approximately, the teacher spends 10 up to 15 minutes in that strategy. If it is to long, then the students run out of time to do their work in writing as the time provided is limited.

The students now are ready to develop the ideas in the form of an initial plan for drafting. They organize the information they have generated during pre-writing. Students who have a place to start with will be more motivated to continue developing their ideas and their own writing activities. Then the students develop an initial plan for the products they will compose by generating the ideas have been discussed.

\section{The Nature of Writing}

Writing, one of the four skills in English language, is a very complex process that al- lows students to explore thoughts, opinions and ideas, and make them visible and concrete. The products of writing - the printed texts are the media of communication between the writers and the readers. Writing is most likely to encourage thinking and learning when students view writing as a process. As every writer uses the process in a different way, the teachers should teach them according to the students' developmental writing stages. Every stage has different characteristics and the teachers should realize the approaches given to the students. 'One fits all' may not be implemented in teaching writing. Obviously, not all students of the same age or grade level write in the same way. Thus the teachers may prepare various activities.

\section{Process writing Activities}

Generally the writing process is seen as consisting of five steps that may serve the needs of Senior High School students. They are pre-writing, writing the first draft, revising, editing, and publishing.

\section{Pre-writing}

Pre-writing, the first step in the writing process, begins before the writher expresses thoughts, ideas or opinions into writing. Within the classroom, pre-writing prompts and activities can be held before the students 
write. This steps enables the students to activate their schemata and prior knowledge concerning with the topic of writing. This activity invites the students to share freely and without any hesitation discuss any ideas that occur to them on a given topic. The students will enjoy the class. Followings are the terms for some techniques used in prewriting activities (Linda et.al 1990:2):

1. Brainstorming is a group of activity in which students freely discuss any thoughts that relate to the given topic.

2. Free-writing is like brainstorming, but the students do it by themselves on paper.

3. Drawing or doodling - making pictures, sketches or cartoons- is an excellent way to begin organizing the students' thoughts about a new topic.

4. Semantic mapping or cluster diagramming is like drawing a map on the students' thoughts, using circles, lines, arrows, and words. It pulls as many different related thoughts out of the students' mind as possible, as quickly as possible.

\section{Writing the First Draft (Drafting)}

As soon as the students have finished gathering ideas and words by means of the various prewriting activities, they are ready to write the first draft. The teacher controls the students' activities and is ready to give some helps if needed. It is strongly recommended that the students just try to write without paying any attention to vocabulary, grammar, and punctuation. If the students stop writing for the sake of thinking of grammar, they will miss some ideas that may occur. The teacher should tell the students to do it in the step of revising.

\section{Revising}

After writing the first draft, the students rethink and rewrite the first draft. They may take the form of reorganizing what has been written in the draft. In this step, the students add or omit some ideas, so that a clearer, more coherent draft is formed better. The students should check to see if the composition has;

a. An introduction in which the main idea is stated.

b. The body, with supporting details, specific examples, and explanations.

c. A conclusion that reflects the content of the introduction.

\section{Editing}

The students do editing as the final step of revising. Special attentions are given to grammar, punctuation, and spelling. They also identify, analyze, and correct their mistakes. The teacher may encourage the students to share their certain pieces or determine the number of pieces that the students are required to share. To end a final, polished draft, the students may write in legible handwriting or use of a word processing program to prepare a polished written work if possible.

\section{Publishing}

In this step, at least the students are ready to submit their final product to the teacher. In addition, they may be given, if possible, a chance to publish their writing products in the forms of class booklets, school paper, yearbook, or even a writing contest or magazines if possible.

\section{METHOD}

The design employed in this research is a collaborative classroom action research (CAR). According to Kasbolah (1998:14), action research is reflective research conducted by giving certain actions to improve or increase the quality of teaching-learning process. In addition, Latief (2008:22) avows that CAR is a means to develop the teachers' technique in teaching and to improve the students' achievement. Thus CAR is intended to improve the quality of teaching learning process in order to improve the students' achievement.

In this research, the researcher worked together with one of the Writing Class lecturers in conducting the action in order to facilitate 
the students who still suffered from difficulties in composing a good paragraph, especially in accessing their own feelings, ideas, experiences, and knowledge. Furthermore, the researcher conducted the action in cyclical process and the collaborative lecturer acted as an observer. The procedures of this research were adapted from Kemmis and McTaggart (1992:5) which consisted of four steps as follows; (1) planning, (2) implementing, (3) observing, and (4) reflecting.

In addition, the research was conducted at the English Department of FKIP Kanjuruhan University which was located, at Jl. Sudanco Supriadi 48 Malang. The subjects of the research were 34 students who were joining Writing I Course Class FR2 (Sunday's Class) due to one major consideration: the problems of writing were found in this class.

In order to obtain the feedbacks related to the implementation of Semantic Mapping strategy, the researcher needed two kinds of data to be collected namely quantitative and qualitative data. Quantitative data were in the form of numbers or scores taken from observation checklist and test. These were the main data to determine the criteria of success. Meanwhile, qualitative data were descriptive data about the teaching-learning process of Writing I Course derived from students and teachers' activities to illustrate the implementation of Semantic Mapping strategy in teaching-learning process.

First of all, the data collected by using observation instrument were the activities of the teacher and the students in the teachinglearning process. When collecting the data related to the teacher's activities, the observer examined whether or not the steps of writing which had been prepared by the researcher and collaborator were applied well by the teacher by giving checklist (V). Meanwhile, the aspects of the students' activities which were observed dealt with the students' activities in every step of the process of writing. The observation was conducted to see the students' involvement in carrying out the expected activities during the implementation stage. The observation checklist was to record and determine the level of the students' participation by giving a mark $(\mathrm{V})$ on provided qualifications.

Next, field notes was another instrument used to record the factual data which might had not been covered in observation checklist such as the phenomena and essential features that occurred in the classroom activities. It includes the setting of the class, the class atmosphere, the interaction between the teacher and the students, and interaction among the students. The instrument also covered good points and things which needed to be improved by the teacher for better implementation of the next meeting.

Last but not least, on-going written test - in the form of writing a descriptive paragraph - was employed to measure how Semantic Mapping strategy was able to improve the students' writing skill. In addition, this test was integrated in the process of writing. Thus the researcher did not provide a specific schedule to carry the test. Realizing that giving a score in a writing product was very subjective, the research utilized inter-rater system in which the teacher and collaborator scored each writing product of the students by applying a coring rubric adapted from Cohen's Analytical Scoring of Assessment (See Appendix 1). Then the scores were divided into two. The average score was the final score of each student.

\section{FINDINGS}

The implementation of Semantic Mapping strategy followed the steps of writing process namely pre-writing, drafting, revising, editing, and publishing. Meanwhile, the strategy was implemented in the step of pre-writing, yet the researcher applied the other steps in carrying out the teaching-learning process of writing. It showed that writing course was not a product-based activity. Rather it needed 
the other steps, or it was a process-based activity.

Some findings of the research revealed that the improvement of the students' writing skill was reflected from the quality of descriptive paragraphs composed by the students and the average score of the students. In addition, the average score of the students in preliminary study was 65.9 and the students who passed the preliminary study were 6 students or $17.6 \%$

In the first cycle, which was conducted in three meetings from May 13 up to May 27, 2012 (on Sundays), the average score of the students was 75.1 where the students who passed the criteria of success (71.0) were 24 or $70.59 \%$.

Meanwhile, in the second cycle, which was conducted in four meetings from June 10 up to July 1, 2012 (on Sundays), the average score of the students was 79.3 where the students who passed the criteria of success $(71,0)$ were 31 or $91.18 \%$.

\section{DISCUSSION}

The implementation of Semantic Mapping strategy was successful to improve the students' writing skill. Apart from the grammatical mistakes made by the students, it was proved that Semantic Mapping strategy facilitated the students to generate their ideas related to the topic. The students were able to explore their ideas and found important terms or vocabulary items and also realized the relationship among the words that they would encounter in their writing related to the topic given that is being discussed.

In addition, Vacca and Vacca state that semantic mapping may be used to depict spatial relationships among words and allow the students to cluster words belonging to categories and to distinguish relationships among words (1998:334). In this step, the teacher provided a model of semantic mapping based on the topic being discussed once or twice so that the students would get a feel for how to develop their own mapping individually or in pairs or in a small group. When a map was used, instruction proceeded from teacher-guided modeling and illustration to student-generated productions. Thus this activity was essential to promote better interaction among the students and the interaction between the teacher and the students since they shared ideas together when constructing a map together.

Meanwhile, the steps of Semantic Mapping strategy can be described below. 
Table 1. The Implementation of Semantic Mapping Strategy

\begin{tabular}{|c|c|c|}
\hline PROCESS OF WRITING & $\begin{array}{l}\text { TEACHER'S } \\
\text { ACTIVITIES }\end{array}$ & $\begin{array}{l}\text { STUDENTS' } \\
\text { ACTIVITIES }\end{array}$ \\
\hline $\begin{array}{l}\text { PRE- } \\
\text { WRITING } \\
\text { ACTIVITIES }\end{array}$ & $\begin{array}{l}\text { - Displaying a picture of } \\
\text { Thukul Arwana } \\
\text { - Activating students' schemata } \\
\text { related to the topic by deliv- } \\
\text { ering questions } \\
\text { - Writing the topic in the mid- } \\
\text { dle of the blackboard } \\
\text { - Having students generating } \\
\text { ideas related to the topic and } \\
\text { complete the map } \\
\text { - Providing help if needed }\end{array}$ & $\begin{array}{l}\text { - Observing the picture } \\
\text { - Answering the questions } \\
\text { and } \\
\text { activating schemata re- } \\
\text { lated to } \\
\text { the text. } \\
\text { - Observing and thinking } \\
\text { of the } \\
\text { topic } \\
\text { - Generating ideas to com- } \\
\text { plete the map together } \\
\text { - Completing the map } \\
\text { (Classical) }\end{array}$ \\
\hline DRAFTING & $\begin{array}{l}\text { - Providing an example of a de- } \\
\text { scriptive paragraph written } \\
\text { based on a map } \\
\text { - Having students write a para- } \\
\text { graph based on the map con- } \\
\text { structed together }\end{array}$ & $\begin{array}{l}\text { - Reading the text, and re- } \\
\text { lating the map and the } \\
\text { text } \\
\text { - Writing a draft individu- } \\
\text { ally }\end{array}$ \\
\hline REVISING & $\begin{array}{l}\text { - Having students revise their } \\
\text { own draft } \\
\text { - Encouraging the students } \\
\text { to have peer check }\end{array}$ & $\begin{array}{l}\text { - Revising the draft } \\
\text { - Exchanging draft and do- } \\
\text { ing } \\
\text { peer check }\end{array}$ \\
\hline EDITING & $\begin{array}{l}\text { - Having students to rewrite } \\
\text { their draft after getting feed- } \\
\text { back } \\
\text { - Asking students to edit the } \\
\text { draft by examining grammar, } \\
\text { spelling, and mechanics. }\end{array}$ & $\begin{array}{l}\text { - Rewriting the draft } \\
\text { - Editing the draft and } \\
\text { writing } \\
\text { the final product }\end{array}$ \\
\hline
\end{tabular}

\section{CONCLUSION}

Semantic Mapping strategy was essential to improve the students' writing skill. The strategy was proved helpful to facilitate the students to generate ideas related to the topic by exploring ideas and finding important terms or vocabulary items and the relationship among the words that they would encounter in their writing related to the topic given.
The strategy was given not only in prewriting activities but also in the other steps of writing. For example, in the step of revising, the students once in a while had to be back to the map to check whether or not they missed some key words. Thus the map was really beneficial to complete the students' product.

In addition, when a map was used, instruction proceeded from teacher-guided modeling and illustration to student-generated productions. 


\section{REFERENCES}

Burns, Paul C, et al, (1996). Teaching Reading in Today's Elementary Schools, Boston: Houghton Mifflin Company

Cohen, A.D. (1994). Assessing Language Ability in the Classroom (2 ${ }^{\text {nd }} E d$.). Boston, MA: Heinle \& Heinle.

Harmer, Jeremy. (2003). The Practice of English Language Teaching. Essex. Pearson Education Limited

Hogue, Ann. (1996). First Step in Academic Writing. New York: Addison Wesley Publishing Company, Inc.

Kemmis, S. and Mc Taggart. (1992). The Action Research Planner. Geelong: Deakin University Press.

Latief, Adnan. (2008). Penelitian Tindakan Kelas Pembelajaran Bahasa Inggris. Penerbit Universitas Negeri Malang. Malang
Roe, D Betty, et al, (1995). Secondary School Reading Instruction - The Content Areas, Boston: Houghton Mifflin Company

Stone, J.M. (1990). Cooperative Learning and Language Arts: A Multi - Structural Approach. San Juan Capistrano: Resources for Teachers

Thomas, R.Murray. (2003). Blending Qualitative and Quantitative Research Methods in Theses and Dissertations. Thousand Oaks: Corwin

Tribble, Christopher, (1996). Writing, Language Teaching: A Scheme for Teacher Education, Oxford: Oxford University Press

Vacca, Richard T. \& Vacca, Jo Anne L. (1999). Content Area reading, New York: Adison-Wesley Educational 